\title{
Phenotypic variation in polyphenolic content of the tropical brown alga Lobophora variegata as a function of nitrogen availability
}

\author{
Thomas M. Arnold*, Christopher E. Tanner, Walter I. Hatch \\ St. Mary's College of Maryland, St. Mary's City, Maryland 20686, USA
}

\begin{abstract}
Although brown algal phlorotannins have been shown to deter certain herbivores and may accumulate in response to herbivory, recent evidence has suggested that concentrations of these polyphenolic compounds are inversely related to nitrogen availability. Previous studies examining the relationship between brown algal phlorotannins and nutrient availability have been conducted in the field and, as a result, other variables may have contributed to observed variations in polyphenolic content. In order to more rigorously test the carbon-nutrient balance hypothesis, clonal isolates of the tropical brown alga Lobophora variegata were cultured for $4 \mathrm{wk}$ in seawater media of 3 nitrogen concentrations $\left(0.2,1.2,5.2 \mathrm{mg} \mathrm{N}^{-1}\right)$. Total phenolic content was determined weekly by a micro-Folin-Denis assay which uses as little as $1 \mathrm{mg}$ of tissue. Percent carbon and nitrogen (per dry weight algal tissue) were also determined weekly for each nutrient treatment. Significant differences (ANOVA, $p<0.001$ ) in phenolic content were observed between nutrient treatments after 2 wk. Phenolic content was directly correlated with tissue $\mathrm{C}: \mathrm{N}$ ratios and inversely correlated with percent tissue nitrogen. Our results support the hypothesis that nitrogen availability plays a role in determining phlorotannin concentrations in brown algae.
\end{abstract}

KEY WORDS: Polyphenols - Phloroglucinol Phlorotannins - Intraspecific variation - Chemical defense . Carbon-nutrient balance $\cdot$ Lobophora variegata Brown algae $\cdot$ Phaeophyceae

\section{INTRODUCTION}

High concentrations of polyphenolic secondary metabolites are found in many terrestrial plants, aquatic vascular plants and brown algae (Phaeophyceae), where they play a putative role in competitive plant fitness. Brown algal polyphenols (phlorotannins) are acetate-malonate derived phloroglucinol (1,3,5-trihydroxybenzene) polymers which are analogous to vascular plant tannins. Concentrations of phlorotannins as high as 25 to $40 \%$ dry weight have been recorded (Ragan \& Glombitza 1986, Tugwell \& Branch 1989, Targett et al. 1992, unpubl.), although the phenolic content of different tissues (Johnson \& Mann 1986, Ragan \& Glombitza 1986, Tugwell \& Branch

\footnotetext{
- Present address: University of Delaware, Graduate College of Marine Studies, Lewes, Delaware 19958, USA
}

1989) and individuals plants within a species (Van Alstyne 1988, Ilvessalo \& Tuomi 1989, Yates \& Peckol 1993) can vary considerably.

Despite biosynthetic dissimilarities (see Waterman \& Mole 1994 for review), algal phlorotannins and vascular plant tannins possess similar characteristic chemical properties that form the basis for ecological activity (Sieburth \& Jensen 1969, McKnight \& Morel 1979, Ragan \& Craigie 1980, Appel 1993). For example, polyphenolics have been observed to deter herbivory (Geiselman \& McConnel 1981, Buchsbuam et al. 1984, Steinberg 1985, 1989, Targett et al. 1986), reduce digestion efficiency by binding to digestive enzymes (Swain 1979, Hagerman \& Butler 1980, Targett \& Targett 1990, Boettcher \& Targett 1993, but see Martin et al. 1987), affect larval development (Esping 1957a, b), and inhibit epiphytic growth (Sieburth \& Conover 1965, McLachlan \& Craigie 1966, Glombitza \& Vogels 1985, Buchsbaum et al. 1990). 
Herbivory can affect patterns of plant distribution and diversity in temperate and tropical plant communities on both ecological and evolutionary time scales (Lubchenco 1978, Cubit 1984, Coley et al. 1985, Gaines 1985, Hay \& Fenical 1988). Hay \& Fenical (1988) estimated that 60 to $97 \%$ of total seaweed annual production in a coral reef community may be removed by herbivores. In plant-herbivore interactions where polyphenols are influential, bioactivity is considered to be primarily, but not exclusively, dose dependent (Geiselman \& McConnel 1981, Targett \& McConnel 1982, Steinberg 1988, Appel 1993, Boettcher \& Targett 1993). As a result, variations in plant allelochemical content may significantly affect many aspects of plant fitness including the percentage of plant production lost to herbivores, and, therefore, influence species composition or population distribution (Feeny 1976, Rhoades \& Cates 1976, Steinberg 1989). Hypotheses attempting to account for both the high concentrations and intraspecific variation of phenolic compounds originated from studies of terrestrial plants and focused on both extrinsic and intrinsic factors affecting various aspects of plant fitness. These hypotheses have been more recently applied to marine plants.

The carbon-nutrient balance hypothesis, as elucidated by Bryant et al. (1983), proposed a link between resource availability and polyphenolic content in boreal plants and, therefore, a possible explanation for observed intraspecific variation (also see Gershenzon 1984, Waterman et al. 1984, Coley et al. 1985). This hypothesis states that polyphenols, carbon-based compounds, will accumulate under conditions of nutrient limitation, when amino acid synthesis is retarded and carbon is in relative excess. Such a relationship may be advantageous because polyphenols would then accumulate under conditions of suppressed protein synthesis when tissue damage originating from herbivory is most difficult to repair. Conversely, chemical defense may be less essential when nitrogen availability is not limiting protein synthesis and tissue damage may be repaired more effectively (Bryant et al. 1983). Indeed, evidence indicates that production of polyphenolic allelochemicals in brown algae and certain species of vascular plants may vary partially or primarily as a function of the internal nutrient balance. For example, Bryant et al. (1987) observed a decrease in polyphenolic content and a related increase in herbivory in the Alaskan paper birch as a result of increased nitrogen availability and shading. Buchsbaum et al. (1990) reported that the polyphenolic content of eelgrass Zostera marina was inversely correlated with tissue nitrogen levels and that low-phenol plants suffered complete mortality from wasting disease. The polyphenolic content of plant cell cultures has also been observed to vary as a function of sucrose addition
(Phillips \& Henshaw 1977) and the C:N internal ratio (Kubek \& Shuler 1980). However, Fajer et al. (1992) and Arnold \& Targett (unpubl. data) found that increasing the carbon content of certain vascular species by elevating environmental $\mathrm{CO}_{2}$ levels did not result in increased production of carbon-based allelochemicals. Ilvessalo \& Tuomi (1989) and Yates \& Peckol (1993) reported that variations in the polyphenolic content of Fucus vesiculosus were correlated with tissue nitrogen and the internal $C: N$ ratio, but not tissue carbon.

Previous studies examining intraspecific variation of brown algal polyphenolic content in relation to nutrient availability have been conducted in the field and, as a result, other environmental and biological variables may have caused or exaggerated the observed variations in phenolic content. Observations indicate that phenotypic variations in plant phenolic content can be correlated with season (Geiselman 1980), light intensity, herbivore pressure (Hay \& Fenical 1988, Van Alstyne 1988), reproductive state (Ragan \& Jensen 1978), and salinity (Pedersen 1984). Also, attempts to utilize a culture system to quantify intraspecific variation have been impeded by the fact that cultured plants rarely retain high levels of phenolic allelochemicals (Ragan \& Glombitza 1986).

In this study a culture isolate of the brown alga Lobophora variegata (Dictyotales, Dictyotaceae) was used to investigate the effects of nitrogen availability on plant phlorotannin content. L. variegata is a cosmopolitan tropical brown alga with several distinct growth forms (Coen \& Tanner 1989), all of which have relatively high concentrations of phenolic compounds (8.33 to $13.39 \%$ of dry weight; Targett et al. 1992). The 'decumbent form' of $L$. variegata is less palatable to fish and crab herbivores than the other forms (Coen \& Tanner 1989) and in some habitats has significantly higher phenolic content (Tanner unpubl. data); however, a relationship between phenolic content and palatability has not been established for the forms of L. variegata.

\section{METHODS}

Spores were isolated from an individual thallus of the decumbent form of Lobophora variegata, collected from a shallow backreef near Carrie Bow Cay, Belize, in July 1989. Cultures from these spores were grown and maintained in enriched seawater medium at $24^{\circ} \mathrm{C}$, with photon irradiances of 50 to $130 \mu \mathrm{mol} \mathrm{m} \mathrm{m}^{-2} \mathrm{~s}^{-1}$ and a light dark cycle of $12: 12 \mathrm{~h}$ until the time of the experiment. In culture, plants reproduced entirely by vegetative means with blades seldom reaching a size of more than $1 \mathrm{~cm}$ in diameter. 
Young, actively growing blades of Lobophora variegata were separated, rinsed with sterile seawater, and transferred to seawater that had passed through algal nutrient scrubbers of the coral reef display tank at the National Museum of Natural History, Smithsonian Institution, Washington, DC (USA). After $3 \mathrm{~d}$, the blades were randomly assigned to one of 3 nitrate treatments $\left(0.2,1.2\right.$, and $5.2 \mathrm{mg} \mathrm{N}^{-1}$ of seawater). Seawater scrubbed by the Smithsonian's coral reef tank $\left(0.2 \mathrm{mg} \mathrm{N} \mathrm{l}^{-1}\right)$ was used as the basal nitrogen treatment. Enriched treatments were prepared by adding sodium nitrate to the basal seawater, and all solutions were sterilized by passing through membrane filters with $0.22 \mu \mathrm{m}$ pores. Each nitrogen treatment was assigned 35 plants, which were subdivided among five $200 \mathrm{ml}$ replicate flasks each containing $150 \mathrm{ml}$ of media. Cultures were agitated continuously for $4 \mathrm{wk}$ in an incubator set at $24^{\circ} \mathrm{C}, 130 \mu \mathrm{mol} \mathrm{m}^{-2} \mathrm{~s}^{-1}$ of photon irradiance, and a light:dark cycle of $12: 12 \mathrm{~h}$. Culture media were replaced once, on Day 18 of the experiment.

A thallus was collected from each flask on Days 8,15 , 22, and 29 for phenolic content and carbon/nitrogen analyses. Thalli, randomly selected from each treatment, were examined microscopically, and morphological changes were noted. All samples were collected at midday to exclude daily fluctuations in plant metabolism as possible factors affecting results. Tissue for total phenolic content determination was weighed and frozen at $-70^{\circ} \mathrm{C}$ for later extraction. Tissue not used to determine phenolic content was pooled for each treatment and dried to constant weight at $40^{\circ} \mathrm{C}$ for carbon/ nitrogen analyses. Carbon and nitrogen content of samples were determined with a Model 440 Leeman $\mathrm{CHN}$ analyzer.

Total phenolic content was determined with a modified Folin-Denis assay which utilizes as little as $1 \mathrm{mg}$ of tissue (Hatch \& Tanner unpubl.). For Days 8, 15, and 22,1 to $5 \mathrm{mg}$ of plant tissue was macerated with a glass rod in $3 \mu \mathrm{l} \mathrm{of} 1.2 \mathrm{~g} \mathrm{ml}^{-1}$ trichloroacetic acid (TCA) to precipitate proteins. This was followed by the addition of $17 \mu \mathrm{l}$ of $50 \%$ acetone, which was found to be more efficient at extracting algal phenolics than 50 or $70 \%$ methanol (Hatch \& Tanner unpubl.). Samples were vortexed and allowed to extract at room temperature for $4 \mathrm{~h}$. Following extraction, samples were assayed for phenolic content as follows: $1000 \mu \mathrm{l}$ of 1:10 Folin-Denis reagent (Association of Official Analytical Chemists 1970) was added to each sample, and immediately vortexed. After $3 \mathrm{~min}, 100 \mu \mathrm{l}$ of saturated sodium carbonate solution was added, followed by vortexing. At the end of $1 \mathrm{~h}$ the samples were centrifuged at $16000 \times g$ for $10 \mathrm{~min}$, and the absorbance of the supernatant was read at $725 \mathrm{~nm}$. Tannic acid equivalents were calculated by comparison to a standard curve of desiccated tannic acid, diluted to $0-20 \mu \mathrm{g} \mathrm{ml}^{-1}$ with $2: 10$ parts of $1.2 \mathrm{~g} \mathrm{ml}^{-1}$ TCA: $50 \%$ acetone and assayed as above. As the entire extract was used in the assay, direct determination of dry weight and the contribution of nonphenolic reactants in the Folin-Denis assay (see Yates \& Peckol 1993) was not possible. Dry weights were estimated using a wet/dry weight ratio determined from samples assayed on Day 29. Specimens from this sample period were assayed with a modification of the above procedures. A sample of 9 to $16 \mathrm{mg}$ of tissue from each replicate was extracted in $20 \mu \mathrm{l}$ of $1.2 \mathrm{~g} \mathrm{ml}^{-1}$ TCA and $100 \mu \mathrm{l}$ of $50 \%$ acetone. After extracting for $4 \mathrm{~h}$, samples were centrifuged for $10 \mathrm{~min}$ and $20 \mu \mathrm{l}$ of each supernatant was assayed as described above. The tissue and remaining extract was dried at $60^{\circ} \mathrm{C}$ for $24 \mathrm{~h}$ and then at $110^{\circ} \mathrm{C}$ for up to $1 \mathrm{wk}$ and weighed.

Differences in phenolic content among plants of the 3 treatments were determined by a 1 -way ANOVA $(\alpha=$ 0.05 ) for each sampling period. Correlations among culture media nitrogen concentrations and plant percent nitrogen, percent carbon, and total phenolic content were determined by a Pearson productmoment correlation $(\alpha=0.05)$.

\section{RESULTS}

By Day 6, all plants exhibited hyaline hairs, nucleated but nonpigmented sterile filaments. Although relative densities of hairs were not quantified, it was evident that plants cultured in $0.2 \mathrm{mg} \mathrm{N}^{-1}$ media possessed a more extensive and dense corona of hyaline hairs than did plants of the $5.2 \mathrm{mg} \mathrm{N}^{-1}$ treatment. Also, there was a noticeable difference in coloration among plants of the 3 nitrogen treatments by Day 15; plants cultured in 0.2 and $1.2 \mathrm{mg} \mathrm{N}^{-1}$ media showed a loss of pigmentation relative to preassay plants while those of the $5.2 \mathrm{mg} \mathrm{N}^{-1}$ media did not.

Significant differences (ANOVA, $p<0.001$ ) in total phenolic content among plants of the 3 nutrient treatments were established by Day 15 (Fig. 1; Table 1). By Day 22 these differences had been disrupted, probably as a result of culture media renewal on Day 18. However, significant differences were reestablished by Day 29. Lobophora variegata cultured in relatively nitrogen-poor conditions consistently possessed higher total phenolic contents than did plants grown in nitrogen-enriched conditions (Table 1).

Specimen C:N ratio tended to reflect culture media nitrogen availability (Table 2 ) throughout the 4 wk. Plants of relatively nitrogen-rich media consistently exhibited lower $\mathrm{C}: \mathrm{N}$ ratios than did plants of nitrogen-poor media. Total phenolic content of Lobophora variegata was inversely related to culture media nitrogen availability and, as a result, to the internal 

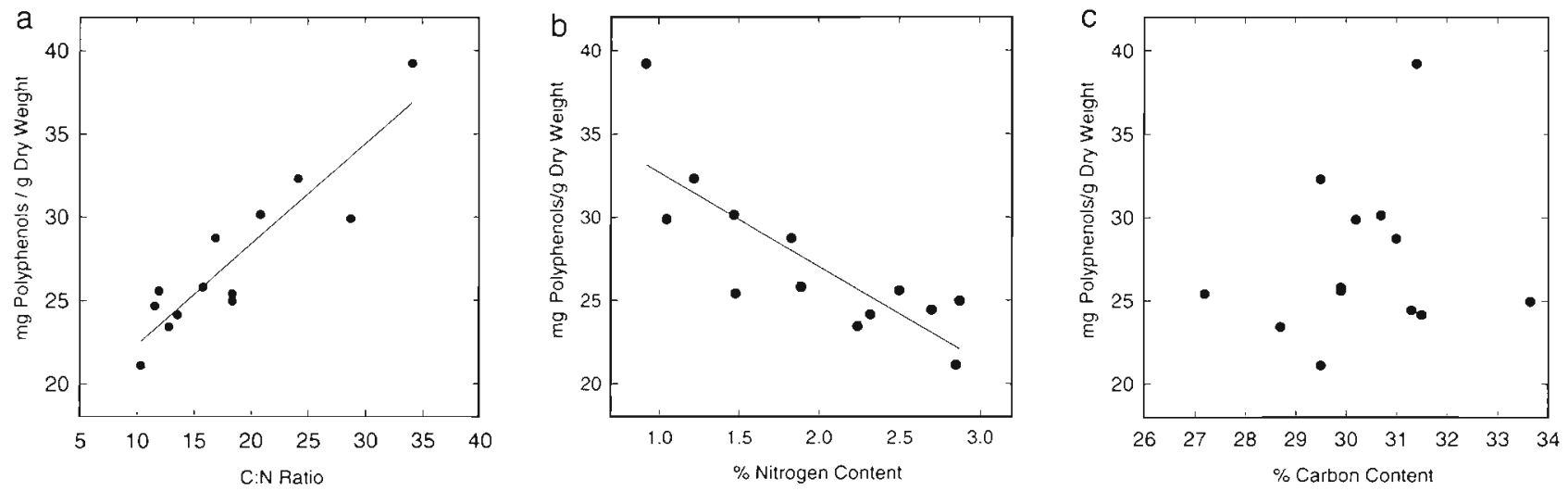

Fig. 2. Lobophora variegata. Culture media nitrogen concentrations affect the internal nutrient balance and the total phenolic content of algal isolates. (a) Phenolic content of $L$. variegata was directly correlated with internal $C: N$ ratio $(p<0.001)$. Specifically, plant phenolic content was correlated with internal nitrogen content (b) but not internal carbon content (c). Points represent the mean of 5 plants and are grouped irrespective of sampling time. Linear regressions (solid line) and $95 \%$ confidence ranges (dotted line) are provided where applicable

(Kubek \& Shuler 1980) or atmospheric $\mathrm{CO}_{2}$ enrichment (Fajer et al. 1992), is often insufficient to cause an increase in carbon-based allelochemicals. Renewal of culture media seems to have affected plant percent nitrogen and total phenolic contents as determined $96 \mathrm{~h}$ later. These data are consistent with a nitrogenlimited system where carbon is in relative excess and suggest that under such conditions, which are common in tropical marine habitats, relatively slight variations in nitrogen availability can cause significant changes in plant phenolic content. We observed significant variation in the total phenolic content of $L$. variegata within a 2 wk period. Interestingly, this time period is similar to that in which Van Alstyne (1988) observed an induced increase in Fucus distichus phenolic content due to simulated herbivore damage (but see Steinberg 1994). Other examinations of resource-dependent vari- ations in brown algal phenolic content (Ilvessalo \& Tuomi 1989, Yates \& Peckol 1993) have focused upon seasonal and monthly variations within field plants.

Previous attempts to manipulate brown algal phenolic content in culture have been hindered by the phenomenon that cultured plants seldom retain significant levels of polyphenols (Ragan \& Glombitza 1986). The phenolic content of cultured Lobophora variegata isolates reported here is considerably lower than that of field plants from Belize (Targett et al. 1992), although phenolic contents of all plants remained above $20 \mathrm{mg}$ phenol $\mathrm{g}^{-1}$, which has been considered by some to be the general lower limit for deterring herbivory. This may be a direct result of the high nutrient levels of commonly employed culture media or of artificially low irradiances, which would affect the internal resource balance. Lapointe et al. (1987) reported substantially

Table 2. Lobophora variegata. Summary of correlations (Pearson product-moment correlation) between phenolic content, C:N ratio, and carbon and nitrogen availability. Pairs with negative coefficients and p below 0.05 have an inverse relationship. Those with positive coefficients and p below 0.05 tend to increase together

\begin{tabular}{|c|c|c|c|c|c|}
\hline & & C:N ratio & $\%$ carbon & $\%$ nitrogen & Treatment N \\
\hline Phenolic content & $\begin{array}{l}\text { Coefficient } \\
\mathrm{p} \\
\mathrm{N}\end{array}$ & $\begin{array}{c}0.919 \\
<0.001 \\
13\end{array}$ & $\begin{array}{c}0.169 \\
0.581 \\
13\end{array}$ & $\begin{array}{c}-0.817 \\
<0.001 \\
13\end{array}$ & $\begin{array}{c}-0.556 \\
0.048 \\
13\end{array}$ \\
\hline C:N ratio & $\begin{array}{l}\text { Coefficient } \\
\mathrm{p} \\
\mathrm{N}\end{array}$ & & $\begin{array}{c}-0.029 \\
0.925 \\
13\end{array}$ & $\begin{array}{c}-0.928 \\
<0.001 \\
13\end{array}$ & $\begin{array}{c}-0.623 \\
0.023 \\
13\end{array}$ \\
\hline$\%$ carbon & $\begin{array}{l}\text { Coefficient } \\
\mathrm{p} \\
\mathrm{N}\end{array}$ & & & $\begin{array}{l}0.283 \\
0.348 \\
13\end{array}$ & $\begin{array}{c}0.074 \\
0.811 \\
13\end{array}$ \\
\hline$\%$ nitrogen & $\begin{array}{l}\text { Coefficient } \\
\mathrm{p} \\
\mathrm{N}\end{array}$ & & & & $\begin{array}{c}0.682 \\
0.010 \\
13\end{array}$ \\
\hline
\end{tabular}


lower nitrogen levels $\left(\mathrm{NH}_{4}{ }^{+}+\mathrm{NO}_{3}{ }^{-}=0.005\right.$ to $0.008 \mathrm{mg}$ $\mathrm{N}^{-1}$ ) at the site from which $L$, variegata was initially isolated for this study. Clearly, culture conditions can greatly affect the phenolic content of brown algae. Our data also suggest that in situ variations in nitrogen availability can cause significant changes in phenolic content in a relatively short period of time. It is unclear whether the variations in plant phenolic content which we observed are of sufficient magnitude to imply ecological significance. However, we observed no leveling off in the trend of increasing phenolic contents, especially for plants of nitrogen-poor media. Therefore, it is possible that plant phenolic contents may continue to increase and may reach concentrations which have been demonstrated to have ecological consequences (Sieburth \& Conover 1965, Steinberg 1985, 1988, 1989, Johnson \& Mann 1986) under such conditions. Such variation in the allelochemical content of the decumbent form of $L$. variegata in relation to nutrient availability may help to explain its predominance in lownutrient, high-herbivory habitats (Coen \& Tanner 1989).

Acknowledgements. This research was supported by a faculty development grant from St. Mary's College of Maryland and NSF Grant SPI-8996152. We thank Paul Hetzer, Hans Lemke, Ty Lindstrom, Egan O'Brien, and Nadine Butler for ideas and encouragement, Dr Nancy Targett, Anne Boettcher, and 3 anonymous reviewers for their critical evaluations of the manuscript, and Kathy Wood (Chesapeake Biological Labs) for help with $\mathrm{C}: \mathrm{N}$ analyses.

\section{LITERATURE CITED}

Appel HM (1993) Phenolics in ecological interactions: the importance of oxidation. J chem Ecol 19(7):1521-1552

Association of Official Analytical Chemists (1970) Tannin (17) - official final action. In: Horwitz W (ed) Official methods of analysis of the AOAC, 11th edn. AOAC, Washington, DC, p 154

Boettcher AA, Targett NM (1993) Role of polyphenolic molecular size in reduction of assimilation efficiency in Xiphister mucosus. Ecology 74(3):891-903

Bryant JP, Chapin FS, Klein DR (1983) Carbon/nutrient balance of boreal plants in relation to vertebrate herbivory. Oikos 40:357-368

Bryant JP, Chapin FS, Reichardt PB, Clausen TP (1987) Response of winter chemical defense in Alaska paper birch and green alder to manipulation of plant carbon' nutrient balance. Oecologia 72:510-514

Buchsbaum RN, Short FT, Cheney DP (1990) Phenolic-rich interactions in eelgrass, Zostera marina L.: possible implications for disease resistance. Aquat Bot 37:291-297

Buchsbaum R, Valiela I, Swain S (1984) The role of phenolic compounds and other plant constituents in feeding by Canada geese in a coastal marsh. Oecologia 63:343-349

Coen L, Tanner CE (1989) Morphological variation and differential susceptibility to herbivory in the tropical brown algae Lobophora variegata. Mar Ecol Prog Ser 54:287-298

Coley PD, Bryant JP, Chapin FS III (1985) Resource availabil- ity and plant antiherbivore defense. Science 230:895-899 Cubit JD (1984) Herbivory and the seasonal abundance of algae on a high intertidal rocky shore. Ecology 65 $1904-1917$

DeBoer JA, Whoriskey FG (1983) Production and role of hyaline hairs in Ceramium rubrum. Mar Biol 77:229-234

Esping U (1957a) A factor inhibiting fertilization of sea urchin eggs from extracts of the alga Fucus vesiculosus. 1. The preparation of the factor inhibiting fertilization. Ark Kemi 11:107-115

Esping U (1957b) A factor inhibiting fertilization of sea urchin eggs from the extracts of the alga Fucus vesiculosus. 2 The effect of the factor inhibiting fertilization on some enzymes. Ark Kemi 11:117-127

Fajer ED, Bowers MD, Bazzaz FA (1992) The effect of nutrients and enriched $\mathrm{CO}_{2}$ environments on production of carbon-based allelochemicals in Plantago: a test of the carbon/nutrient balance hypothesis. Am Nat 140(4):707-723

Feeny PP (1976) Plant apparency and chemical defences. Rec Adv Phytochem 10:1-42

Gaines SD (1985) Herbivory and between-habitat diversity: the differential effectiveness of defenses in a marine plant Ecology 66(2):473-485

Geiselman JA (1980) Ecology of chemical defenses of algae against the herbivorous snail, Littorina littorea, in the New England rocky intertidal community. PhD dissertation. Woods Hole Oceanographic Institute/Massachusetts Institute of Technology, Woods Hole

Geiselman JA, McConnell OJ (1981) Polyphenols in brown algae Fucus vesiculosus and Ascophyllum nodosum: chemical defenses against the marine herbivorous snail. Littorina littorea. J chem Ecol 7:1115-1133

Gershenzon J (1984) Changes in the levels of plant secondary metabolites under water and nutrient stress. In: Timmermann BN, Steelink C, Loewus FA (eds) Phytochemical adaptations to stress. Plenum Press, New York, p 273-320

Glombitza KW, Vogels HP (1985) Antibiotics from algae. 35 Phlorotannins from Ecklonia maxima. Planta Med 51: $308-312$

Hagerman AE, Butler LG (1980) Determination of protein in tannirn-protein precipitates. J agric Fd Chem 28:944-947

Hay MA, Fenical W (1988) Marine plant-herbivore interactions: the ecology of chemical defense. A Rev Ecol Syst 19:111-145

Hurd CL, Galvin RS, Norton TA, Dring MJ (1993) Production of hyaline hairs by intertidal species of Fucus (Fucales) and their role in phosphate uptake. J Phycol 29:160-165

Ilvessalo H, Tuomi J (1989) Nutrient availability and accumulation of phenolic compounds in the brown alga Fucus vesiculosus. Mar Biol 101:115-119

Johnson CR, Mann KH (1986) The importance of plant defense abilities to the structure of subtidal seaweed communities: the kelp Laminaria longicruris de la Pylaie survives grazing by the snail Lacuna vincta (Montagu) at high population densities. J exp mar Biol Ecol 97:231-267

Kubek DJ, Shuler ML (1980) The effect of variations in carbon and nitrogen concentrations on phenolics formation in plant cell suspension cultures. J Nat Prod 43\{1):87-96

Lapointe BE, Littler MM, Littler DS (1987) A comparison of nutrient-limited productivity in macroalgae from a Caribbean barrier reef and from a mangrove ecosystem. Aquat Bot 23:245-255

Lubchenco J (1978) Plant species diversity in a marine rocky intertidal community: importance of herbivore food preference and algal competitive abulities. Am Nat 112:23-39

Martin JS, Martin MM, Bernays EA (1987) Failure of tannic acid to inhibit digestion or reduce digestibility of plant 
protein in gut fluids of insect herbivores: implications for theories of plant defense. J chem Ecol 13:605-621

Mcknight DM, Morel FMM (1979) Release of weak and strong copper-complexing agents by marine algae. Limnol Oceanogr 24:287-292

McLachlan J. Craigie JS (1966) Antialgal activity of some simple phenols. J Phycol 2:133-135

O'Connor KA, West JA (1991) The effect of light and nutrient conditions on hair cell formation in Spyridia filamentosa (Wulfen) Harvey (Rhodophyta). Botanica mar 34:359-364

Pedersen A (1984) Studies on phenol content and heavy metal uptake in fucoids. Proc int Seaweed Symp 11:498-504

Phillips R, Henshaw GG (1977) The regulation of synthesis of phenolics in stationary phase cell culture of Acer pseudoplantanus L. J exp Bot 28:785-794

Ragan MA, Craigie JS (1980) Quantitative studies on brown algal phenols. IV. Ultraviolet spectrophotometry of extracted polyphenols and implications for measuring dissolved organic matter in sea water. J exp mar Biol Ecol 46: 231-239

Ragan MA, Glombitza KW (1986) Phlorotannins, brown algal polyphenols. Prog phycol Res 4:130-230

Ragan MA, Jensen A (1978) Quantitative studies on brown algal phenols. II. Seasonal variation in polyphenol content of Ascophyllum nodosum (L.) Le Jol. and Fucus vesiculosus (L.). J exp mar Biol Ecol 34:245-258

Rhoades DF, Cates RG (1976) Toward a general theory of plant antiherbivore defense. Rec Adv Phytochem 10: $168-213$

Sieburth JMCN, Conover JT (1965) Sargassum tannin, an antibiotic which retards fouling. Nature 208:52-53

Sieburth JMcN, Jensen A (1969) Studies on algal substances in the sea. II. The formation of gelbstoff (humic material) by exudates of phaeophyta. $J$ exp mar Biol Ecol 3:275-289

Steinberg PD (1985) Feeding preferences of Tegula funebralis and chemical defenses of marine brown algae. Ecol Monogr 55(3):333-349

Steinberg PD (1988) Effects of quantitative and qualitative variation in phenolic compounds on feeding in three species of marine invertebrate herbivores. J exp mar Biol Ecol 120:221-237

Steinberg PD (1989) Geographic variation in the interaction between marine herbivores and brown algal secondary

This article was submitted to the editor metabolites. In: Paul VJ (ed) Ecological roles of marine natural products. Comstock Publishing, Cornell Unversity Press

Steinberg PD (1994) Lack of short-term induction of phlorotannins in the Australasian brown algae Ecklonia radiata and Sargassum vestitum. Mar Ecol Prog Ser 112 $129-133$

Swain $T$ (1979) Tannins and lignins. In: Rosenthal GA Janzen DH (eds) Herbivores: their interactions with secondary plant metabolites. Academic Press, New York, p $657-682$

Targett NM, Coen LC, Boettcher AA, Tanner CE (1992) Biogeographic comparisons of marine algal polyphenolics: evidence against a latitudinal trend. Oecologia 89: $464-470$

Targett NM, McConnell OJ (1982) Detection of secondary metabolites in marine macroalgae using the marsh periwinkle, Littorina irrorata Say, as an indicator organism. J chem Ecol 8(1):115-124

Targett NM, Targett TE, Vrolijk N, Ogden JC (1986) Effect of macrophyte secondary metabolites on the feeding preferences of the herbivorous parrotfish Sparisoma radians. Mar Biol 92:141-148

Targett TE, Targett NM (1990) Energetics of food selection by the herbivorous parrotfish Sparisoma radians: roles of assimilation efficiency, gut evacuation rate, and algal secondary metabolites. Mar Ecol Prog Ser 66:13-21

Tugwell S, Branch GM (1989) Differential polyphenolic distribution among tissues in the kelps Ecklonia maxima, Laminaria pallida, and Macrocystis angustifolia in relation to plant defense theory. J exp mar Biol Ecol 129(3):387-401

Van Alstyne KL (1988) Herbivore grazing increases polyphenolic defenses in the intertidal brown algal Fucus distichus. Ecology 96(3):655-663

Waterman PG, Mole S (1994) Analysis of phenolic plant metabolites. Blackwell, Oxford

Waterman PG, Ross JAM, McKey DB (1984) Factors affecting levels of some phenolic compounds, digestibility, and nitrogen content of the mature leaves of Barteria fistulosa (Passifloraceae). J chem Ecol 10:387-401

Yates JL, Peckol P (1993) Effects of nutrient availability and herbivory on polyphenolics in the seaweed Fucus vesiculosus. Ecology 74(6):1757-1766

Manuscript first received: November 15, 1994

Revised version accepted: February 7, 1995 